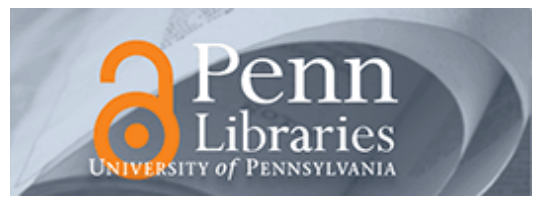

University of Pennsylvania

ScholarlyCommons

Accounting Papers

Wharton Faculty Research

$11-2013$

\title{
The Ombudsman: Are Top Executives Paid Enough? An Evidence- Based Review
}

Philippe Jacquart

J. Scott Armstrong

University of Pennsylvania

Follow this and additional works at: https://repository.upenn.edu/accounting_papers

Part of the Accounting Commons, and the Marketing Commons

Recommended Citation

Jacquart, P., \& Armstrong, J. S. (2013). The Ombudsman: Are Top Executives Paid Enough? An EvidenceBased Review. Interfaces, 43 (6), 580-589. http://dx.doi.org/10.1287/inte.2013.0705

This paper is posted at ScholarlyCommons. https://repository.upenn.edu/accounting_papers/99

For more information, please contact repository@pobox.upenn.edu. 


\title{
The Ombudsman: Are Top Executives Paid Enough? An Evidence-Based Review
}

\author{
Abstract \\ Our review of the evidence found that the notion that higher pay leads to the selection of better executives \\ is undermined by the prevalence of poor recruiting methods. Moreover, higher pay fails to promote better \\ performance. Instead, it undermines the intrinsic motivation of executives, inhibits their learning, leads \\ them to ignore other stakeholders, and discourages them from considering the long-term effects of their \\ decisions on stakeholders. Relating incentive payments to executives' actions in an effective manner is \\ not possible. Incentives also encourage unethical behavior. Organizations would benefit from using \\ validated methods to hire top executives, reducing compensation, eliminating incentive plans, and \\ strengthening stockholder governance related to the hiring and compensation of executives.

\section{Keywords} \\ bonus, cooperatives, corporate governance, democracy, employee selection, executive compensation, \\ incentives, index methods, judgmental bootstrapping, Mondragon, motivation, pay, performance, \\ stakeholders \\ Disciplines \\ Accounting | Marketing
}




\title{
Are Top Executives Paid Enough? An Evidence-Based Review
}

\author{
Version R12-clean \\ Philippe Jacquart \\ EMLYON Business School, Lyon, France, jacquart@em-lyon.com
}

\section{J. Scott Armstrong}

The Wharton School, University of Pennsylvania, Philadelphia, Pennsylvania Adjunct Researcher, Ehrenberg-Bass Institute, University of South Australia, Adelaide, South Australia, armstrong@wharton.upenn.edu

Our review of the evidence found that the notion that higher pay leads to the selection of better executives is undermined by the prevalence of poor recruiting methods. Moreover, higher pay fails to promote better performance. Instead, it undermines the intrinsic motivation of executives, inhibits their learning, leads them to ignore other stakeholders, and discourages them from considering the long-term effects of their decisions on stakeholders. Relating incentive payments to executives' actions in an effective manner is not possible. Incentives also encourage unethical behaviour. Organizations would benefit from using validated methods to hire top executives, reducing compensation, eliminating incentive plans, and strengthening stockholder governance related to the hiring and compensation of executives.

Key words: bonus; cooperatives; corporate governance; employee selection; executive compensation; incentives; index method; judgmental bootstrapping; Mondragon; intrinsic motivation; pay; performance; stakeholders.

History: This paper has been refereed. 
In 2008, Fortune 500 CEOs were paid 185 times more than the average worker (DeNavas-Walt et al. 2009). Academics and the general public have questioned the justification for such large payments to executives. A Gallup poll conducted in June 2009 found that 59 percent of a representative sample of 998 Americans favored government action to limit executive compensation (Jones 2009).

\section{Problem}

Boards of directors set the compensation of their top executives to attract capable people and to encourage them to act in the firm's interests. In effect, the board must forecast which candidates will do the most effective job and how they will respond to the level and type of remuneration. This forecasting task is complex because potential executives vary on many dimensions, as do firms. The primary method used for this task is unaided expert judgment-i.e., unaided by any evidence-based forecasting methods (see Armstrong 2001a).

Decades of research have led to a perplexing finding on unaided judgments: beyond a basic minimum, expertise has no value for forecasting outcomes in complex, uncertain situations. Nevertheless, people continue to believe experts' forecasts. This is known as the seer-sucker theory: "No matter how much evidence exists that seers do not exist, suckers will pay for the existence of seers” (Armstrong 1980 p. 2).

Research since 1980 has added support to the conclusion that unaided judgments are unsuitable for management forecasting for complex uncertain situations. In particular, see Tetlock’s (2005) analysis of over 82,000 forecasts in a 20-year study of 284 experts, 
whose professions involve offering advice on political and economic trends. These experts barely outperformed laymen in the accuracy of their forecasts, and their forecasts were less accurate than those derived from simple decision rules.

Given the difficulty of learning from experience, recruiters may be unaware of the factors affecting their perceptions of job applicants' suitability. In one experiment, participants viewed videotaped job interviews. Unbeknownst to them, professional actors wore special prostheses to play overweight job candidates in the experimental condition and then played themselves—average-weight candidates—in the control condition. All of the participants were presented with the same resumes and job descriptions. When participants viewed overweight job candidates, they made more negative inferences about them $(r=-.45)$ and reported they would be less willing to hire them $(r=-.59)$ (Pingitore et al. 1994). Studies on the beauty premium also show evidence of such bias. One study concluded that workers who ranked in the lowest 9 percent in terms of looks earned between 7 and 9 percent less than average, whereas workers who ranked in the top third earned 5 percent more than the average (Hamermesh and Biddle 1994). We are unaware of evidence that slim and attractive people are better managers.

\section{Methodology}

We sought experimental and quasi-experimental studies (i.e., analyses of data for which key explanatory variables differed, while many but not all other variables were held constant) to assess how remuneration motivated managers and affected firm performance. Non-experimental data are less useful for assessing causal effects, although we do draw on such analyses to some extent. With non-experimental data, the relationship between executive pay and firm performance is confounded, because firms with high profits pay 
higher compensation to CEOs. Analyses of experimental data are preferable for identifying causality in such situations involving complexity and uncertainty (Armstrong 2012a).

To locate relevant studies, we searched the ABI/Inform, PsychINFO, and SSCI databases (search terms: “compensation OR pay AND performance”), examined the publication records of researchers whose work is relevant to the questions at hand, scanned reference lists of all relevant papers that we obtained, and contacted key researchers to ask whether we might have missed relevant sources.

Academic papers frequently misstate findings in their reviews of prior research (Wright and Armstrong 2008). To address this, we contacted authors whose findings we summarized in substantive ways. If we received no reply, we followed up with another email. In all, we received replies from $80 \%$ of the authors whom we contacted. Information about the studies is provided in supplementary material to this paper at https://www.informs.org/Pubs/Interfaces/Online-Supplements.

\section{Does Higher Pay Lead Firms to Hire More Effective Executives?}

One argument for high executive compensation is that firms must compete for the best managers by offering higher pay. This assumes firms use validated selection procedures. However, human resources (HR) practitioners hold fallacious views regarding personnel selection. For example, intelligence is the single best predictor of job performance (Schmidt and Hunter 1998), yet only 18 percent of the 959 HR professionals surveyed by Rynes et al. (2002) identified intelligence as a better predictor of job performance than conscientiousness. Similarly, when personnel experts in New Zealand and the United States were asked to rank the strength of job-performance predictors, the correlation 
between the experts' rankings and the evidence-based rankings was close to zero (Ahlburg 1992; Dakin and Armstrong 1989). Two surveys of 820 British recruitment consultants found that executives are generally selected using unstructured interviews and character references, procedures with little validity (Clark 1992).

Perhaps the most serious shortcoming of executive recruiting is the failure to apply Meehl’s (1954) rule, summarized here as: "You should not meet job candidates until you decide to make them an offer." Instead, Meehl advised the use of linear models (e.g., regression analysis). In interviews, irrelevant factors (e.g., height, body build, gender, accent and looks) often dominate relevant factors. Additional research has continued to support Meehl's findings (see Grove 2000 for a meta-analysis).

Few organizations follow Meehl's rule. However, its adoption by the Oakland Athletics baseball team had an enormous impact. Although the team had a modest payroll, it won a high percentage of its games. After initial resistance, other baseball teams also adopted these superior prediction methods, as did basketball and football teams (Armstrong 2012c). These teams believed they needed to adopt the method to stay competitive. Adoption by business firms has been slow; this is unfortunate, because we expect that using Meehl's rule would help all stakeholders.

Executives are often evaluated on the basis of the success or failure of the business unit for which they are responsible. In practice, many internal and external factors influence outcomes for firms, and assessing the role played by a given executive is not possible. For example, should a manager get credit for a firm's success when the economy is booming or blame for the firm's losses during a recession? When answering such questions, evaluators are biased toward ignoring contextual factors and overly 
attributing outcomes to leaders. This bias was illustrated in a laboratory experiment in which groups of participants had to solve a coordination task. In the experiment, group size varied, and participants could perceive that the task was harder when the group was larger. Despite this, participants credited group leaders for the success of small groups and blamed them for the failure of large groups (Weber et al. 2001).

Nonexperimental studies also find that increases in CEO compensation occur following increases in firm performance that result from factors beyond the CEO's control—CEOs are paid for being lucky. For example, CEOs in the oil industry were compensated for increases profits resulting from fluctuations in the price of crude oil-a factor beyond their control (Bertrand and Mullainathan 2001).

If the selection procedures do not use evidence-based procedures, then one would not expect executive search firms to add benefit over what a firm could do on its own. In addition, they can do this at a lower cost given that leading executive search firms charge about one-third of the first year's compensation or roughly one million dollars for each CEO hired (Settimi 2008).

\section{Does Higher Pay Lead to Better Performance?}

We present evidence on the relationship between pay and performance, and also examine the special case of large financial bonuses. We then discuss the specific structure and implications of executive incentive programs.

\section{Pay and Performance}

One study examined the performance of CEOs after receiving awards, such as CEO of the year or top manager, from the press (e.g., Business Week). In the year of the awards, 
the total compensation of superstar CEO winners increased by 44 percent; however, the compensation of all non-winners showed little increase. This also applied to the nonwinners who were most similar to winners based on individual and firm characteristics; their compensation closely approximates what the superstar CEOs would have received had they not been given the awards. Three years following the awards, the difference in total compensation between the superstars and similar CEOs remained substantial. However, following the awards, the stocks of firms led by superstar CEOs underperformed as their by 15 to 26 percent compared to firms led by similar CEOs in the three-year period after the awards (Malmendier and Tate 2009).

The predominant view among economists is that monetary rewards motivate people to perform better.

Literature reviews (e.g., Prendergast 1999, Gerhart et al. 2009) and a number of meta-analyses (e.g., Cameron and Pierce 1994, Eisenberger and Cameron 1996) support the positive effect of pay on performance.

One meta-analysis examined the relationship between pay and performance across 39 laboratory and field experiments. Pay had no effect on performance in terms of quality, but did affect performance measures in terms of quantity $(r=.34)$, leading the authors to conclude that their results, along with similar results from previous metaanalyses, went "a long way towards dispelling the myth that financial incentives erode intrinsic motivation” (Jenkins et al. 1998, p. 784).

In contrast, psychologists tend to argue that the relationship between monetary rewards and performance depends on the situation Especially important is the distinction 
between extrinsic motivation (rewards) and intrinsic motivation (satisfaction in doing the task).

A meta-analysis of 128 experiments concluded that extrinsic rewards undermine intrinsic motivation (Deci et al. 1999). Previous meta-analyses had reached similar conclusions (Rummel and Feinberg 1988, Tang and Hall 1995, Wiersma 1992). The Deci et al. meta-analysis corrected for a number of shortcomings in some of the meta-analyses we cited in support of the economists' view on incentives (i.e., Cameron and Pierce 1994, Eisenberger and Cameron 1996). For example, Cameron and Pierce (1994) omitted almost 20 percent of relevant studies, misclassified certain studies, and most importantly, did not consider relevant conditions (e.g., whether the tasks were inherently motivating).

Deci et al.’s meta-analysis of 128 laboratory experiments further examined the relationship between extrinsic rewards and intrinsic motivation by considering a number of moderating conditions. When rewards were tangible, expected, and contingent on performance — as they are for executives—-the correlation between rewards and intrinsic motivation was -0.28 (based on 32 studies). The decrease in motivation was even greater when rewards were tangible, expected, and contingent on completion (i.e., when rewards were given only to those doing very well); the correlation, based on 19 studies, was -0.44 (Deci et al. 1999). Literature reviews (e.g., Frey and Jegen 2001) also support the detrimental effect of incentives on motivation and performance.

A meta-analysis involving 46 laboratory and field experiments that controlled for the nature of the tasks found a negative relationship between tangible rewards and performance for interesting tasks (i.e., tasks perceived as challenging, enjoyable or purposeful), and a positive relationship between tangible rewards and performance for 
less interesting tasks (Weibel et al. 2010). For example, there was a positive relationship between tangible rewards and performance for a simple task like installing automobile windows (Lazear 2000); however, there was a negative relationship for difficult and/or interesting tasks like resolving complex mathematical problems (Mowen et al. 1981). [Better example, Phil?] Specifically, the correlation between monetary rewards and work performance was positive $(r=0.42)$ for simple or boring tasks, but negative $(r=-0.13)$ for interesting or difficult tasks. Five experiments examined how performance was affected by the use of incentives and by how severely non-optimal answers were sanctioned. With incentives participants were more concerned with evaluating how well they were doing than with understanding how the task should be done, leading to poorer performance for more complex tasks (Hogarth et al. 1991).

\section{Incentive Systems}

The second author of this paper started his career as an engineer and was involved with designing incentive payments for repetitive tasks that require little thinking. This was used only when it was possible to tie individual efforts directly to outcomes in situations in which other factors have negligible effects. These systems also require extremely accurate performance measures. Once in place, it was common for workers to falsify their productivity accounts to increase their pay. In addition, conditions change over time so that incentives frequently need updating. Workers point out changes that call for increased effort, but those that reduce effort (the more common situation). Engineers did not believe that incentive standards were possible for even the first level of supervision.

Consider the effects of particularly large financial incentives. In a field experiment, participants completed tasks requiring creativity, attention, concentration, 
and memory, and were randomly informed that exceptional performance would be rewarded by a small, medium, or large financial bonus (i.e., equivalent salary for a day, two weeks, or five months, respectively). Participants in the medium-bonus condition did not perform better than participants in the small-bonus condition; participants in the large-bonus condition performed the poorest (Ariely et al. 2009). When researchers replicated this experiment using functional magnetic resonance imaging to monitor participants' brain activity, they found that the prospect of obtaining larger-than-average rewards engaged a relatively large share of attention and working memory, leaving little available to effectively carry out tasks (Mobbs et al. 2009).

Incentive plans can be detrimental to the interests of shareholders when the plans focus on short-term performance at the expense of long-term profitability. See Bebchuk and Fried (2010) for a review. Additionally, incentive systems may affect executives in unintended ways. Increased emphasis on profits or on any other single measure is likely to lead to reduced emphasis and even detrimental effects on other measures (Slovic and MacPhillamy 1974), such as the treatment of other stakeholders. For example, in a laboratory experiment, participants were asked if they would be willing to keep a profitable drug, Panalba, on the market in the face of overwhelming evidence that it was killing patients. They were told that drugs made by competitors provided the same benefits without causing fatalities. When playing the role of top executives and board members, no group removed the drug from the market. The participants were adhering to their task of increasing profits. However, groups that were asked to also consider the 
drug's effects on stakeholders and were given estimates of these effects were more likely to withdraw the drug (Armstrong 1977).

Financial incentives can lead to undesirable behaviors by executives. In a series of experiments on ethical behavior, financial incentives weakened or outweighed the participants’ sense of moral self-identity. For example, participants were more likely to lie in an actual negotiation when personal financial incentives were involved (Aquino et al. 2009).

Incentive plans are likely to temp executives to engage in fraudulent behavior. For example, school superintendents in Philadelphia were asked to improve their students’ standardized test scores. Some superintendents were highly successful and were sought after by other schools. However, the key factor to their success was that they put a program in place to erase wrong answers on student exams and insert correct answers (Russ 2012).

Yermack (1997) noticed a pattern in which stock options grants for CEO coincided with favorable movements in the stock price. The fraudulent nature of this became clear years when Lie (2005) examined almost 6,000 CEO stock option awards granted between 1992 and 2002 and found stock options were often granted on the day when the value of these options would be maximized.

\section{Possible Solutions}

We discuss four improvements in executive compensation: (1) use evidence-based procedures for the selection and compensation of top executives; (2) reduce executive pay; (3) eliminate incentive payments for executives; and (4) improve corporate 
governance by giving stockholders more control over the hiring, retention, and compensation of top executives.

\section{Use Evidence-Based Methods for Selection, Compensation, and Promotion}

A meta-analysis of 85 years of research on employee selection found that general mental ability (intelligence) is the single-best predictor of job performance, especially in jobs involving decision-making in complex situations (Schmidt and Hunter 1998). These data are non-experimental, and range restriction applies because people generally apply only for jobs for which they think they are capable. Schmidt and Hunter found that the number of years of education was not correlated to long-term job performance when the analysis controlled for the effect of cognitive abilities (e.g., IQ). A review of experimental studies, also reached this conclusion (Armstrong 2012b).

Biases can be avoided by making observers blind to irrelevant candidate characteristics. A study of symphonic orchestra auditions found that when applicants performed behind a screen, the probability that female candidates passed preliminary rounds of recruitment increased by 50 percent (Goldin and Rouse 2000).

Much evidence exists about factors that affect job performance. This information should be used in a structured fashion to improve reliability and to help control for biases. When many important variables and good knowledge about the directional effects of the variables are present, index models allow the use of all prior information in a simple manner (see Armstrong and Graefe 2011 for evidence). Index models require only an assessment of the directional impact of each variable on the criterion, such as assigning a score of $+1(-1)$ if a variable has a positive (negative) effect on the criterion of interest. The sum of the scores serves as the predictive index—highest score wins. 
Given the difficulty of developing objective performance measures for executives, judgmental bootstrapping offers a way to improve an expert's predictions. Used in the early 1900s to forecast agricultural crop yields, this method was applied successfully to personnel predictions and other management problems in the latter part of the $20^{\text {th }}$ century (Armstrong 2001b). By using an experimental design with artificially created data (to avoid inter-correlation among the predictor variables), one can develop a model by regressing an expert's forecasts on the variables used. For example, the expert forecasts the success of 50 applicants, and his forecasts are regressed against the information provided to the expert. Validation studies have shown that the model's predictions are almost always more accurate than those the expert provided because the model applies the expert's rules more consistently. This approach can also identify when the expert is using irrelevant variables.

Sealed bids, a commonly used market-based procedure for hiring contractors of all types, might be considered for hiring top executives. Applicants using sealed bids would describe what they could do for the organization, what relevant skills they have (and support for their claims), how much they would require in remuneration, how long a contract they would need, and whether they would require any payments should they be asked to resign. The proposals would be cleaned to eliminate information that does not relate clearly to job performance (e.g., gender, race, religion, weight, height, voice or looks). The bids would then be sent to a screening committee who would make blind, independent ratings using a structured rating sheet.

Candidates who pass the initial screening would then go to an assessment center, where traits (e.g., cognitive abilities, values, and self-control) would be evaluated. In one 
study, 382 top executives (e.g., CEOs, presidents, board chairpersons and controllers) completed an assessment of their values. They were then given an in-basket exercise for their decisions prior to leaving on a business trip. The tasks included descriptions of seven situations in which they could earn higher profits by using fraudulent accounting practices. Overall, they used fraudulent reports in 44 percent of their decisions. Interestingly, those who placed a high value on self-respect were less likely to make fraudulent decisions than those who placed a high value on extrinsic rewards. (Brief et al. 1996).

Assessment centers would also include evaluations of skills, such as the ability to use evidence-based techniques for running effective meetings, analyzing data, listening to others, writing persuasive reports, and developing strategic plans. These results could be entered into an index model to identify the leading candidates.

Current procedures for selecting CEOs seem to rely heavily on the use of analogies. For example, “Ms. X was successful in running division A in company B, so she should do well in running our company because it is in a similar business.” Analogies can produce useful forecasts if used as inputs to forecasts (Green and Armstrong 2007). This suggests that organizations should look for suitable candidates among those currently working in the organization. An internal candidate's performance would be more relevant given the similarities of domain knowledge, job function, product line, company culture and managerial style. In addition, peers, subordinates, and superiors can rate internal candidates.

One study compared the performance of external hires against that of internal employees promoted to similar positions within a US investment banking division 
between 2003 and 2009. Although the external hires had more experience and education, and were paid 15 percent more in the two years following their recruitment, they performed worse on the job and were more likely to leave the company, as opposed to employees recruited internally (Bidwell 2011). Harris and Helfat (1997) also found that externally hired CEOs were paid more than CEOs promoted internally.

A policy of hiring from within might lead ambitious people to identify more closely with the firm and motivate them to prove their importance to the firm rather than trying to attract outside offers. Promotion from within has been used with apparent success by family-run firms, churches, the military, and many for-profit firms. We suspect that it is the dominant approach used by small firms. Many CEOs take pride in developing people to succeed them. We will not bother to mention examples such as Apple, which lost their way when they hired outsiders as CEOs.

\section{Reduce the Compensation of Top Executives}

Given the lack of evidence favoring high pay and the evidence on its detrimental effects, we conclude that compensation of top executives should gradually be reduced. Given the nature of the job (and the status associated with the position), many capable people would accept a modest salary for a top management position. Indeed, cooperatives and voluntary organizations often offer low salaries, yet they have no difficulty in finding top executives.

\section{Eliminate Incentive Payments to Executives}

Jensen and Murphy (1990) supported a movement toward incentive payments for top management with an influential study (as of mid-2013, Google Scholar showed more than 5,000 citations for this paper). They argued that compensation should be designed to 
motivate those in top management to serve the firm, rather than their own interests. They suggested three guidelines: (1) require that CEOs hold a substantial amount of company stock, (2) make the levels and structure of compensation sensitive to firm performance, and (3) fire CEOs for poor performance. No experimental evidence was provided to support these guidelines.

\section{Improve Corporate Governance}

Corporate governance plays an important role in keeping executive compensation in check. For example, in the aforementioned study of CEO compensation in the oil industry (Bertrand and Mullainathan 2001), pay for luck was 23 to 33 percent lower in firms where CEO power was weaker because of the presence of a large investor on the board.

A study of how CEO compensation changed in response to luck (i.e., events affecting firm performance beyond the CEO’s control) between 1992 and 2011 showed that pay was about 25 percent higher when luck favored the CEO. However, this effect was evident only in poorly governed firms. (Garvey and Milbourn 2006).

Similarly, in the superstar CEO study, the deleterious effects following awards to CEOs were most pronounced in in which management was more entrenched or shareholder protection was weaker (Malmendier and Tate 2009).

A study of CEO incentive payments in over 1,000 firms between 1992 and 2003 found that the extent to which CEOs had power over their boards explained between 10 and 30 percent of the variance in incentive pay and performance. Furthermore, greater CEO power was associated with decreased firm value and performance during that period (Morse et al. 2011). 
One study found that opportunistic timing of option grants was more likely in firms with weaker corporate governance. This was measured by whether or not a firm's board had a majority of independent directors, by whether or not the firm's compensation committee included an outside shareholder with a large number of shares, and by the length of CEO tenure (Bebchuk et al. 2010).

Studies of anti-takeover legislation show evidence that executive compensation increases with executive power. Following these anti-takeover legislations, which entrenched management, compensation levels increased, particularly among white-collar workers, and the firm's market value diminished (Bertrand and Mullainathan 1999, 2003). The effects of weakened corporate governance on executive compensation can spread to other firms because peer-group benchmarking is often used to set executive compensation. Consider the Delaware court rulings that strengthened firms' anti-takeover legislations. These court rulings led not only to a substantial increase in CEO compensation for firms incorporated in Delaware. It also affected firms outside Delaware because they used the CEO compensation of their competitors in Delaware as a benchmarks to set the compensation of their CEOs (Bereskin and Cicero 2012).

Following corporate scandals in the early 2000s, US stock exchanges issued board requirements to limit the power of CEOs. A quasi-experimental study examined how this change in corporate governance affected CEO pay by observing changes in compensation between firms already following these requirements and firms that were not. These requirements reduced CEO pay between 2000 and 2005 in a sample of 865 firms listed in the S\&P 1500 index. Furthermore, CEO compensation was 17 percent lower in firms that 
were more affected by these requirements compared to firms that were already generally complying with these requirements (Chhaochharia and Grinstein 2009).

In a study examining the relationship between management entrenchment and a firm's financial performance between 1990 and 2003, entrenchment was found to correlate negatively with firm valuation, as measured both by stock returns and the firm's estimated worth. Entrenchment was measured by an index based on the following provisions: "staggered boards, limits to shareholder bylaw amendments, poison pills, golden parachutes, and supermajority requirements for mergers, and charter amendments” (Bebchuk et al. 2009, p. 783).

A natural field experiment in corporate governance can be found in the Basque region of Spain where the democratically run Mondragon Cooperative Corporation (Mondragon) is based. The "Mondragon experiment” began with a single cooperative in 1956 and grew to 256 organizations employing over 100,000 people by 2012. From 1996 to 2008, its sales increased by more than 213 percent, while sales in conventional firms operating in the same sectors in Spain increased by only 140 percent.

The ownership of firms in the Mondragon cooperative is vested in the employees who elect their own managers. The governing council is effectively a board of directors that is responsible for electing the CEO and for approving the CEO's choice of senior executives. Indeed, the top executives have no vote on the governing council. In effect, the owners control the process. The general idea is to promote from within, because the employee-owners have excellent knowledge about the candidates. The top executive is a 
servant to those in the organization. If those in the organization believe they are being poorly served, they can replace the executive.

CEOs in Mondragon receive no incentive payments. The compensation of the highest-paid employee is set to a maximum of 8.9 times that of the least-paid employee (this ratio has increased after many years to retain top managers in response to market pressures). If all sources of compensation are included, this ratio is currently 11:1.

The Mondragon ratio is higher than the 5:1 maximum ratio used by most cooperatives (Arando et al. 2011). Because of these salary differential restrictions, if the CEO should receive a salary increase, then all employees would receive a commensurate salary increase.

Some US companies follow similar guidelines. For example, at Whole Foods, the maximum top salary is currently set at 18 times the average salary (Sutherland 2013). These companies seem to have no problem attracting people willing to become their CEOs. The case of Mondragon suggests that firms and their stockholders might benefit from introducing at least some degree of employee ownership.

An organization that does not find the evidence to date persuasive might consider what evidence would lead them to make changes. They could then search for such evidence, commission an experiment, or try alternative approaches.

\section{Conclusions}

High pay levels do not lead to the selection of more effective managers. One reason is that executive recruiters often fail to use evidence-based selection procedures. This includes failure to use valid indicators of job performance and failure to use evidence- 
based methods, such as regression analysis, judgmental bootstrapping, and the index method. Particularly important to removing bias, the decisions should be made prior to meeting the potential candidates (Meehl's rule).

High levels of executive pay have not been shown to lead to better performance. Given this, owners should consider paying lower levels of remuneration to top executives. One way to implement this is to provide an open search with a preference for hiring from within the firm, and invite applicants to submit sealed bids on the positions.

Incentive payments are inappropriate for top executives. They lead executives to focus on invalid measures, reducing their ability to learn and encouraging unethical behavior.

Weak corporate governance allows CEOs to increase their compensation. Stockholders should have greater control over selection and remuneration procedures.

When it comes to executive selection and remuneration, a stark contrast exists between experimental findings and current practice.

\section{Online Supplement}

An online supplement to this paper is available as part of the online version that can be found at https://www.informs.org/Pubs/Interfaces/Online-Supplements.

\section{Acknowledgments}

We gratefully acknowledge the contributions of Dennis Ahlburg, Chris Armstrong, Kay Armstrong, Ed Deci, Andreas Graefe, Kesten C. Green, Robin Hogarth, Derek Jones, Gueorgui Kolev, Brian Martin, Don Peters, and Adrian Tschoegl. Each provided useful 
suggestions on earlier versions of this paper. Timothy Chow, Jennifer Kwok and Alice Mack edited the paper. All mistakes and omissions are ours. This paper was written while the first author was sponsored as a visiting postdoctoral fellow at The Wharton School, University of Pennsylvania, by a Swiss National Science Foundation grant (grant number PBLAP1-132966).

\section{References}

Ahlburg DA (1992) Predicting the job performance of managers: What do the experts know? Internat. J. Forecasting 7(4):467-472.

Aquino K, Freeman D, Reed A, Felps W, Lim VK (2009) Testing a social-cognitive model of moral behavior: The interactive influence of situations and moral identity centrality. J. Personality Sociol. Psych. 97(1):123-141.

Arando S, Freundlich F, Gago M, Jones DC, Kato T (2011) Assessing Mondragon: Stability and managed change in the face of globalization. Carberry E, ed. Employee Ownership and Shared Capitalism: New Directions in Research (ILR Press/Cornell University Press, Ithaca, NY).

Ariely D, Gneez U, Loewenstein G, Mazar N (2009) Large stakes and big mistakes. Rev. Econom. Stud. 76(2):451-469.

Armstrong JS (1977) Social irresponsibility in management. J. Bus. Res. 5(3):185-213.

Armstrong JS (1980) The seer-sucker theory: The value of experts in forecasting. Tech. Rev. 83(7):16-24.

Armstrong JS (2001a) Principles of Forecasting (Kluwer Academic Publishers, Boston). 
Armstrong JS (2001b) Judgmental bootstrapping, Principles of Forecasting, (Kluwer Academic Publishers, Boston), pp 171-192.

Armstrong JS (2012a) Illusions in regression analysis. Internat. J. Forecasting 28(3):689694.

Armstrong JS (2012b) Natural learning in higher education. Seel NM, ed. Encyclopedia of the Sciences of Learning (Springer, New York), pp 2426-2433.

Armstrong JS (2012c) Predicting job performance: The moneyball factor. Foresight Internat. J. Appl. Forecasting 25:31-34.

Armstrong JS, Graefe A (2011) Predicting elections from biographical information about candidates: A test of the index method. J. Business Res. 64(7):699-706.

Bebchuk LA, Cohen A, Ferrell A (2009) What matters in corporate governance? Rev. Financial Stud. 22(2):783-827.

Bebchuk LA, Fried JM (2010) Paying for long-term performance. University Pennsylvania Law Rev. 158(7):1915-1959.

Bebchuk LA, Grinstein Y, Peyer U (2010) Lucky CEOs and lucky directors. J. Finance 65(6):2363-2401.

Bereskin FL, Cicero DC (2012) CEO compensation contagion: Evidence from an exogenous shock. J. Financial Econom. 107(2):477-493.

Bertrand M, Mullainathan S (1999) Is there discretion in wage setting? A test using takeover legislation. Rand J. Econom. 30(3):535-554.

Bertrand M, Mullainathan S (2001) Are CEOs rewarded for luck? The ones without principles are. Quart. J. Econom. 116(3):901-932. 
Bertrand M, Mullainathan S (2003) Enjoying the quiet life? Corporate governance and managerial preferences. J. Political Econom. 111(5):1043-1075.

Bidwell M (2011) Paying more to get less: Specific skills, matching, and the effects of external hiring versus internal promotion. Admin.Sci. Quart. 56(3):369-407.

Brief AP, Dukerich JM, Brown PR, Brett JF (1996) What's wrong with the treadway commission report? Experimental analyses of the effects of personal values and codes of conduct on fradulent financial reporting. J. Bus. Ethics 15(2):183-198.

Cameron J, Pierce WD (1994) Reinforcement, reward, and intrinsic motivation: A metaanalysis. Rev. Ed. Res. 64(3):363-423.

Chhaochharia V, Grinstein Y (2009) CEO compensation and board structure. J. Finance 64(1):231-261.

Clark T (1992) Management selection by executive recruitment consultancies: A survey and explanation of selection methods. J. Managerial Psych. 7(6):3-10.

Dakin S, Armstrong JS (1989) Predicting job performance: A comparison of expert opinion and research findings. Internat. J. Forecasting 5(2):87-194.

Deci EL, Koestner R, Ryan RM (1999) A meta-analytic review of experiments examining the effects of extrinsic rewards on intrinsic motivation. Psych. Bull. 125(6):627-668.

DeNavas-Walt C, Proctor BD, Smith JC (2009) Income, poverty, and health insurance coverage in the United States: 2008. U.S. Census Bureau, Washington, DC.

Eisenberger R, Cameron J (1996) Detrimental effects of reward: Reality or myth? Amer. Psychologist 51(11):1153-1166. 
Frey BS, Jegen R (2001) Motivation crowding theory. J. Econom. Surveys 15(5):589611.

Garvey GT, Milbourn TT (2006) Asymmetric benchmarking in compensation:

Executives are rewarded for good luck but not penalized for bad. J. Financial Econom. 82(1):97-225.

Gerhart B, Rynes SL, Fulmer IS (2009) Pay and performance: Individuals, groups, and executives. Acad. Management Ann. 3(1):251-315.

Goldin C, Rouse C (2000) Orchestrating impartiality: The impact of "blind" auditions on female musicians. Amer. Econ. Rev. 90(4):715-741.

Green KC, Armstrong JS (2007) Structured analogies for forecasting. Internat. J. Forecasting 23(3):365-376.

Grove WM, Zald DH, Lebow B. S., Snitz B. E., Nelson,C (2000) Clinical versus mechanical prediction: A meta-analysis. Psychological Assessment 12:19-30.

Hamermesh DS, Biddle JE (1994) Beauty and the labor market. Amer. Econom. Rev. 84(5):1174-1194.

Harris D, Helfat C (1997) Specificity of CEO human capital and compensation. Strategic Management J. 18(11):895-920.

Hogarth RM, Gibbs BJ, McKenzie CRM, Marquis MA (1991) Learning from feedback: Exactingness and incentives. J. Experimen . Psych. Learning Memory Cognition 17(4):734-752.

Jenkins GD, Mitra A, Gupta N, Shaw JD (1998) Are financial incentives related to performance? A meta-analytic review of empirical research. J. Appl. Psych. 83(5):777-787. 
Jensen MC, Murphy KJ (1990) Performance pay and top-management incentives. $J$. Political Econom. 98(2):225-264.

Jones JM (2009) Most Americans favor gov't. action to limit executive pay. Accessed May 1, 2013, http://www.gallup.com/poll/120872/americans-favor-gov-actionlimit-executive-pay.aspx.

Lazear EP (2000) Performance pay and productivity. Amer. Econom. Rev. 90(5):13461361.

Lie E (2005) On the timing of CEO stock option awards. Management Sci. 51(5):802812.

Malmendier U, Tate G (2009) Superstar CEOs. Quart. J. Econom. 124(4):1593-1638.

Meehl PE (1954) Clinical vs. Statistical Prediction: A Theoretical Analysis and a Review of the Evidence (University of Minnesota Press, Minneapolis, MN).

Mobbs D, Hassabis D, Seymour B, Marchant JL, Weiskopf N, Dolan RJ, Frith CD (2009) Choking on the money: Reward-based performance decrements are associated with midbrain activity. Psych. Sci. 20(8):955-962.

Morse A, Nanda V, Seru A (2011) Are incentive contracts rigged by powerful CEOs? J. Finance 66(5):1779-1821.

Mowen JC, Middlemist RD, Luther D (1981) Joint effects of assigned goal level and incentive structure on task-performance: A laboratory study. J. Appl. Psych. 66(5):598-603.

Pingitore R, Dugoni BL, Tindale RS, Spring B (1994.) Bias against overweight job applicants in a simulated employment interview. J. Appl. Psych. 79(6):909-917. 
Prendergast C (1999) The provision of incentives in firms. J. Econom. Literature 37(1):7-63.

Rummel A, Feinberg R (1988) Cognitive evaluation theory: A meta-analytic review of the literature. Sociol. Behav. Personality 16(2):147-164.

Russ V (2012) School district's pssa test scores drop. Accessed April 22, 2013, http://articles.philly.com/2012-09-23/news/34041720_1_math-scores-charterschools-budget-for-city-schools.

Rynes SL, Colbert AE, Brown KG (2002) HR professionals' beliefs about effective human resource practices: Correspondence between research and practice. Human Resource Management 41(2):149-174.

Schmidt FL, Hunter JE (1998) The validity and utility of selection methods in personnel psychology: Practical and theoretical implications of 85 years of research findings. Psych. Bull. 124(2):262-274.

Settimi C (2008) The executive recruitment trap. Accessed April 22, 2013, http://www.forbes.com/2008/12/19/recruiting-executive-chief-leadershipgovernance-cx_cs_1219recruit.html.

Slovic P, MacPhillamy DJ (1974) Dimensional commensurability and cue utilization in comparative judgment. Organ. Behavior Human Performance 11(2):172-194.

Sutherland B (2013) Whole Foods’ Mackey says employees should come before investors. Accessed April 22, 2013, http://www.bloomberg.com/news/2013-0118/whole-foods-mackey-says-employees-should-come-before-investors.html. Tang SH, Hall VC (1995) The overjustification effect: A meta-analysis. Appl. Cognitive Psych. 9(5):365-404. 
Tetlock PE (2005) Expert Political Judgment: How Good is it? How can we Know? (Princeton University Press, Princeton, NJ).

Weber R, Camerer C, Rottenstreich Y, Knez M (2001) The illusion of leadership: Misattribution of cause in coordination games. Organ. Sci. 12(5):582-598.

Weibel A, Rost K, Osterloh M (2010) Pay for performance in the public sector benefits and (hidden) costs. J. Public Admin. Res. Theory 20(2):387-412.

Wiersma UJ (1992) The effects of extrinsic rewards in intrinsic motivation: A metaanalysis. J. Occupational Organ. Psych. 65(2):101-114.

Wright M, Armstrong JS (2008) The ombudsman: Verification of citations: Fawlty towers of knowledge? Interfaces 38(2):125-139.

Yermack D (1997) Good timing: CEO stock option awards and company news announcements. J. Finance (52):449-476. 